\title{
Further studies on the hypocholesterolæmic effect of soya-bean protein in rats*
}

\author{
BY Y. NAGATA, K. TANAKA AND M. SUGANO† \\ Laboratory of Nutrition Chemistry, Kyushu University School of Agriculture, Fukuoka \\ 812 Japan
}

(Received 30 June $1980-$ Accepted 1 September 1980)

1. The hypocholesterolamic effect of soya-bean protein compared with that of casein, when fed at $200 \mathrm{~g} / \mathrm{kg}$ diet for 3 weeks, was studied in rats.

2. Using a cholesterol-free low-fat $(10 \mathrm{~g}$ maize oil $/ \mathrm{kg})$ diet, the hypocholesterolæmic effect was demonstrated not only with soya-bean protein but also with an amino acid mixture simulating this protein. The addition of lysine to these diets did not modify their intrinsic effects on serum cholesterol.

3. By feeding the vegetable protein or its amino acid mixture, both high-density-lipoprotein-and verylow-density-lipoprotein plus low-density-lipoprotein-cholesterol decreased to a similar extent, and the concentration of serum apolipoprotein A-I decreased and that of apolipoprotein B increased.

4. Although rats given soya-bean protein excreted more neutral and acidic steroids, the difference disappeared when the amino acid mixture was fed, indicating that the hypocholesterolamic effect of the vegetable protein is not ascribed only to the increased elimination of steroids.

5. It is likely that the difference in the amino acid composition between animal and vegetable proteins is in fact responsible for the different response of serum cholesterol.

Available knowledge regarding the effects of dietary proteins on plasma cholesterol levels in humans and several experimental animals suggests that plant proteins, in particular soya-bean protein, generally exert a hypocholesterolæmic effect as compared with animal protein such as casein (Carroll \& Hamilton, 1975; Hamilton \& Carroll, 1976; Huff \& Carroll, 1977; Huff et al. 1977; Yadav \& Liener, 1977; Carroll et al. 1977, 1978; Sirtori et al. 1977, 1979; Belton \& Truswell, 1978; Fumagalli et al. 1978; Kim et al. 1978; Hevia \& Visek, 1979; Hevia et al. 1979; Noseda et al. 1979; Nagata et al. 1980), though Neves et al. (1980) failed to demonstrate such an effect of plant proteins.

It has been pointed out that the effect of soya-bean protein on plasma cholesterol is easily modified by the type of diet (Hamilton \& Carroll, 1976; Hevia \& Visek, 1979; Kritchevsky et al. 1977). In our previous experiments with rats, the hypocholesterolæmic effect of soya-bean protein isolate compared with that of casein could be demonstrated only when the animals were given a cholesterol-free low-fat diet (Nagata et al. 1980). Neves et al. (1980) have reported recently that pure and crude plant proteins, when compared with the corresponding animal proteins, do not have a hypocholesterolæmic potential in rats. The diets of Neves et al. (1980) contained $100 \mathrm{~g}$ soya-bean oil $/ \mathrm{kg}$, and this level is suspected to be too high to demonstrate the cholesterol-lowering effect of plant proteins. Even at the level of $50 \mathrm{~g}$ maize oil $/ \mathrm{kg}$, the hypocholesterolæmic effect of the soya-bean protein isolate was greatly reduced (Nagata et al. 1980). Previous studies have shown that in rats plant proteins were hypocholesterolæmic only when they were already made hypercholesterolæmic with possibly essential-fatty-acid-deficient diets (Yadav \& Liener, 1977).

- The preliminary part of the study was presented at the 7th International Symposium on Drugs Affecting Lipid Metabolism, Milan, June 1980.

$\uparrow$ For reprints. 
Only limited evidence is available concerning the mechanism of the hypocholesterolæmic effect of soya-bean protein. Since there is still controversy as to whether the plant protein itself or the non-protein contaminants (Oakenfull et al. 1979; Potter et al. 1979; Sautier et al. 1979) present in the preparation are responsible for the cholesterol-lowering potential, the effect of an amino acid mixture simulating soya-bean protein isolate or casein on serum cholesterol levels of rats was compared in the present paper. Simultaneously, the effect on serum high-density lipoprotein-cholesterol and several apolipoproteins as well as on the excretion of steroids in faeces were examined. In some trials, the study was also designed to investigate the effect of supplementary amino acids on the cholesterol metabolism.

\section{METHODS \\ Animals and diets}

Male Wistar rats (Kyudo Co., Kumamoto) were used throughout. The animals were given a commercial diet (Type NMF; Oriental Yeast Co., Tokyo) for at least 1 week before the start of the experiments. When they weighed $150-160 \mathrm{~g}$ they were transferred to individual stainless-steel cages and maintained at $20-21^{\circ}$ with alternating $12 \mathrm{~h}$ periods of light (08.00-20.00 hours) and dark and they were given the experimental diets ad lib. for 3 weeks. Food consumption and body-weight were recorded three times each week. At the end of each experiment, rats were fasted (18.00-09.00 hours), killed by decapitation and blood collected. The composition of the basal diet was $(\mathrm{g} / \mathrm{kg})$ : nitrogen source 200 , maize oil 10 , mineral mixture 40 , vitamin mixture (water-soluble) 10 , choline chloride $1 \cdot 5$, cellulose powder 20 , and sucrose to $1 \mathrm{~kg}$. The $\mathbf{N}$ sources were casein (vitamin-free containing $145 \mathrm{~g} \mathrm{~N} / \mathrm{kg}$ dry matter; ICN Pharmaceuticals Inc., Cleveland Ohio), soya-bean protein isolate (Fujipro $\mathrm{R}$ containing $144 \mathrm{~g} \mathrm{~N} / \mathrm{kg}$ dry matter; Fuji Oil Co., Osaka) (Nagata et al. 1980) and amino acid mixtures (Ajinomoto Co., Tokyo and Kyowa Hakko Kogyo Co., Tokyo) simulating casein and soya-bean protein isolate. The compositions of the amino acid mixtures are shown in Table 1 , which were based on analyses by the manufacturer, Yadav \& Liener (1977) and that of the present study. The vitamin mixture (Oriental Yeast Co.) was prepared according to Harper (1959). Mineral mixtures according to Harper (1959) or Ebihara et al. (1979) were used for protein diets or amino-acid-mixture diets respectively; the latter mixture contained an extra amount of zinc compared with the former. Fat-soluble vitamins which were dissolved in maize oil contained $(/ \mathrm{kg})$ : retinyl palmitate $4000 \mu \mathrm{g}$, cholecalciferol $50 \mu \mathrm{g}$, DL- $\alpha$-tocopheryl acetate $100 \mathrm{mg}$. Supplementation of lysine or arginine was achieved at the expense of sucrose. In order to make the arginine:lysine value in these $\mathrm{N}$ sources identical, $8.6 \mathrm{~g}$ arginine or $17.2 \mathrm{~g}$ lysine $/ \mathrm{kg}$ were added to diets containing animal or vegetable proteins respectively.

\section{Lipid analysis}

Blood serum was obtained by centrifugation. Serum and liver lipids were extracted and analyzed for cholesterol, triglyceride and phospholipid as described previously (Nagata $e t$ al. 1980). Serum high-density-lipoprotein (HDL)-cholesterol was measured in the supernatant fraction obtained after dextran sulphate (Daiichi Seiyaku Co., Tokyo) precipitation of very-low-density (VLDL) and low-density-lipoproteins (LDL) (Burnstein et al. 1970). The concentrations of apolipoproteins A-I, B and E were determined by rocket immunoelectrophoresis (Imaizumi et al. 1978). Hydroperoxide was measured by fluorometry according to Yagi (1976). Faeces were collected for $2 \mathrm{~d}$ at the end of each experiment and analysed for neutral (Miettinen et al. 1965) and acidic steroids (Grundy et al. 1965) by gas-liquid chromatography.

\section{Statistical analysis}

Data were analysed by the Student's $t$ test (Fisher, 1970). 
Table 1. Composition of amino acid mixtures simulating soya-bean protein or casein

\begin{tabular}{|c|c|c|}
\hline \multirow[b]{2}{*}{ L-Amino acids } & \multicolumn{2}{|c|}{ Composition (g/kg diet)* } \\
\hline & Casein & $\begin{array}{c}\text { Soya-bean } \\
\text { protein }\end{array}$ \\
\hline Ala & $4 \cdot 78$ & 8.44 \\
\hline Arg & 6.88 & $15-18$ \\
\hline Asp & 13.82 & $22 \cdot 80$ \\
\hline Cys & 2.36 & 2.96 \\
\hline Glu & $43 \cdot 20$ & $38 \cdot 40$ \\
\hline Gly & 3.62 & $8 \cdot 36$ \\
\hline His & 5.98 & 4.96 \\
\hline Ileu & 8.52 & $7 \cdot 36$ \\
\hline Leu & 17.32 & $14 \cdot 30$ \\
\hline Lys & 14.38 & $14 \cdot 16$ \\
\hline Met & 4.68 & $2-46$ \\
\hline Phe & 10.08 & $10 \cdot 16$ \\
\hline Pro & $20 \cdot 20$ & 12.90 \\
\hline Ser & 11.56 & 11.24 \\
\hline Thr & 8.50 & 8.02 \\
\hline Trp & 1.66 & 2.84 \\
\hline Tyr & 10.84 & $7 \cdot 38$ \\
\hline Val & 11.62 & 8.04 \\
\hline
\end{tabular}

* The values are based on values provided by Yadav \& Liener (1977), the manufacturer and the present study.

\section{RESULTS}

\section{Serum and liver lipid concentration}

Table 2 summarizes weight gain, food intake, liver weight and the concentration of serum and liver triglyceride and phospholipid. In each experiment, there were no differences in food intake and weight gain in relation to the type of dietary proteins or amino acid mixtures. On feeding a diet containing protein as the $\mathbf{N}$ source, liver weight was slightly but significantly higher in rats given casein than in the animals given soya-bean protein. This was not the situation when the animals were given amino-acid-mixture diets. Differences in the nature of the dietary $\mathrm{N}$ sources, either proteins or amino acid mixtures, did not cause uniform changes in the concentrations of serum and liver triglyceride and phospholipid, although in some instances there were small differences between the two groups. The addition of specific amino acids to the diet displayed no additional effects on these lipid components, except for the increase in serum triglyceride of rats given diets containing soya-bean protein or its amino-acid-mixture supplemented with lysine.

Cholesterol levels in serum and liver are shown in Table 3. Both soya-bean protein and its amino acid mixture exhibited a hypocholesterolæmic effect by comparison with the corresponding casein diets. The cholesterol-lowering effect of the vegetable protein was mainly attributable to the decrease in HDL-cholesterol, the net decrease in VLDL plus LDL-cholesterol being considerably lower. However, the proportion of the HDL-cholesterol relative to total cholesterol in rats given diets containing soya-bean protein or its amino-acid-mixture was similar to or even higher than that in rats given the corresponding casein diets. The addition of lysine did not modify greatly the hypocholesterolæmic effect of soya-bean protein or its amino-acid-mixture. Also, no changes in serum cholesterol were observed even after the addition of arginine to casein or its amino-acid-mixture. Although the liver cholesterol level was higher in the casein than in soya-bean protein groups, replacing the amino acid mixture for the protein obscured the difference. 


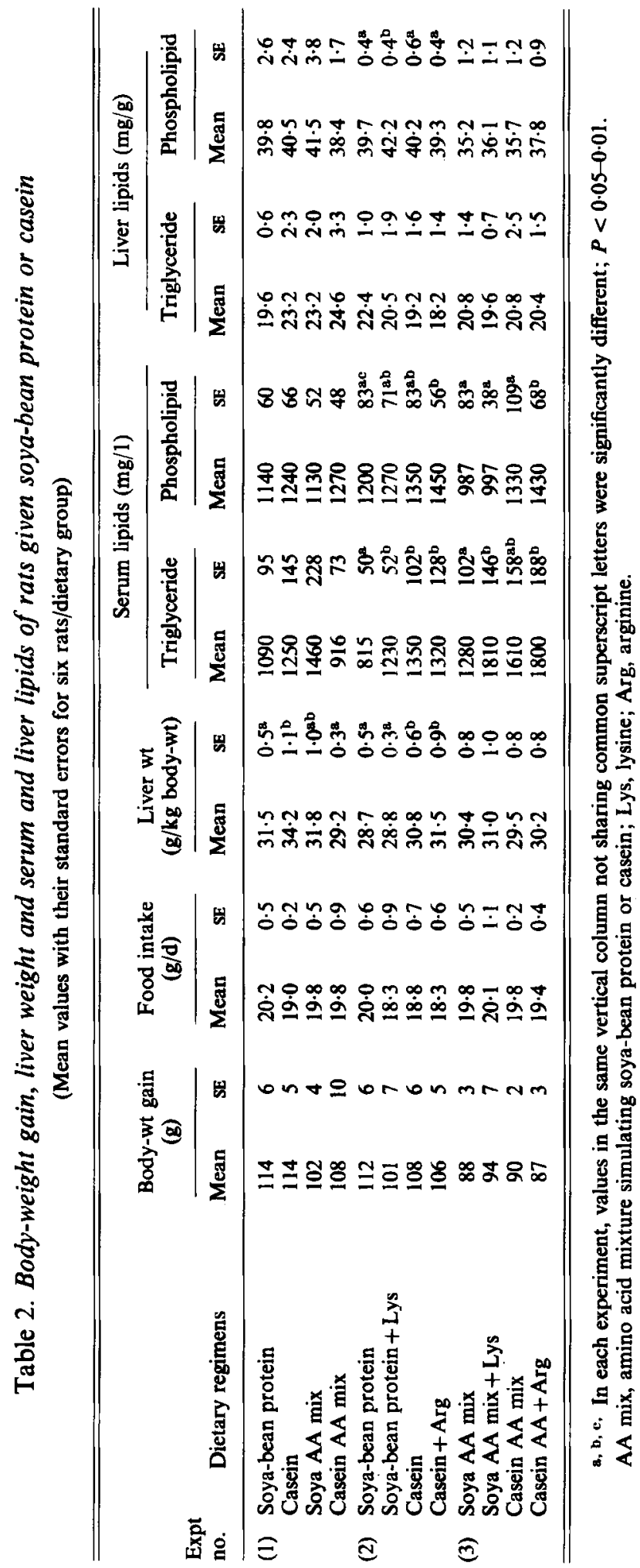


Table 3. Concentration of serum and liver cholesterol in rats given soya-bean protein or casein

(Mean values with their standard errors for six rats/dietary group)

\begin{tabular}{|c|c|c|c|c|c|c|c|c|c|}
\hline \multirow{3}{*}{\multicolumn{2}{|c|}{ Expt no. Dietary regimes }} & \multicolumn{6}{|c|}{ Serum cholesterol $(\mathrm{mg} / \mathrm{l})$} & \multirow{2}{*}{\multicolumn{2}{|c|}{$\begin{array}{c}\text { Liver } \\
\text { cholesterol } \\
(\mathrm{mg} / \mathrm{g})\end{array}$}} \\
\hline & & \multicolumn{2}{|c|}{$\begin{array}{c}\text { Total } \\
\text { cholesterol }\end{array}$} & \multicolumn{2}{|c|}{$\begin{array}{l}\text { HDL- } \\
\text { cholesterol }\end{array}$} & \multicolumn{2}{|c|}{$\begin{array}{l}\text { LDL- } \\
\text { cholesterol }\end{array}$} & & \\
\hline & & Mean & SE & Mean & $\mathbf{s E}$ & Mean & $\mathbf{S E}$ & Mean & SE \\
\hline (1) & $\begin{array}{l}\text { Soya-bean protein } \\
\text { Casein } \\
\text { Soya AA mix } \\
\text { Casein AA mix }\end{array}$ & $\begin{array}{l}693 \\
872 \\
726 \\
873\end{array}$ & $\begin{array}{l}50^{\mathrm{a}} \\
54^{\mathrm{bc}} \\
59^{\mathrm{ab}} \\
29^{\mathrm{c}}\end{array}$ & $\begin{array}{l}508 \\
596 \\
522 \\
645\end{array}$ & $\begin{array}{l}25^{\mathrm{a}} \\
26^{\mathrm{bc}} \\
31^{\mathrm{ab}} \\
19^{\mathrm{c}}\end{array}$ & $\begin{array}{l}185 \\
277 \\
205 \\
228\end{array}$ & $\begin{array}{l}41 \\
46 \\
32 \\
35\end{array}$ & $\begin{array}{l}3 \cdot 2 \\
3 \cdot 7 \\
3 \cdot 5 \\
3 \cdot 2\end{array}$ & $\begin{array}{l}0 \cdot 1^{\mathrm{B}} \\
0 \cdot 2^{\mathrm{b}} \\
0 \cdot 1^{\mathrm{ab}} \\
0 \cdot 1^{\mathrm{a}}\end{array}$ \\
\hline (2) & $\begin{array}{l}\text { Soya-bean protein } \\
\text { Soya-bean protein }+ \text { Lys } \\
\text { Casein } \\
\text { Casein }+ \text { Arg }\end{array}$ & $\begin{array}{l}536 \\
626 \\
757 \\
813\end{array}$ & $\begin{array}{l}45^{\mathrm{a}} \\
49^{\mathrm{ab}} \\
74^{\mathrm{bc}} \\
40^{\mathrm{e}}\end{array}$ & $\begin{array}{l}381 \\
357 \\
471 \\
487\end{array}$ & $\begin{array}{l}30^{\mathrm{a}} \\
25^{\mathrm{a}} \\
50^{\mathrm{ab}} \\
33^{\mathrm{b}}\end{array}$ & $\begin{array}{l}155 \\
269 \\
286 \\
326\end{array}$ & $\begin{array}{l}20^{\mathrm{a}} \\
25^{\mathrm{b}} \\
26^{\mathrm{b}} \\
28^{\mathrm{b}}\end{array}$ & $\begin{array}{l}2 \cdot 9 \\
2 \cdot 9 \\
3 \cdot 3 \\
3 \cdot 3\end{array}$ & $\begin{array}{l}0 \cdot 1^{\mathrm{a}} \\
0 \cdot 1^{\mathrm{a}} \\
0 \cdot 1^{\mathrm{b}} \\
0 \cdot 1^{\mathrm{b}}\end{array}$ \\
\hline (3) & $\begin{array}{l}\text { Soya AA mix } \\
\text { Soya AA mix + Lys } \\
\text { Casein AA mix } \\
\text { Casein AA mix + Arg }\end{array}$ & $\begin{array}{l}666 \\
674 \\
938 \\
980\end{array}$ & $\begin{array}{l}57^{\mathrm{a}} \\
33^{\mathrm{a}} \\
78^{\mathrm{b}} \\
87^{\mathrm{b}}\end{array}$ & $\begin{array}{l}427 \\
406 \\
557 \\
579\end{array}$ & $\begin{array}{l}32^{\mathrm{a}} \\
23^{\mathrm{a}} \\
25^{\mathrm{b}} \\
29^{\mathrm{b}}\end{array}$ & $\begin{array}{l}239 \\
269 \\
372 \\
401\end{array}$ & $\begin{array}{l}29^{\mathrm{a}} \\
17^{\mathrm{ab}} \\
67^{\mathrm{ab}} \\
62^{\mathrm{b}}\end{array}$ & $\begin{array}{l}3 \cdot 9 \\
3 \cdot 5 \\
3 \cdot 6 \\
3 \cdot 4\end{array}$ & $\begin{array}{l}0.1 \\
0.1 \\
0.1 \\
0.2\end{array}$ \\
\hline
\end{tabular}

a, b, c. In each experiment, values in the same vertical column not sharing common superscript letters were significantly different; $P<0.05-0.01$.

AA mix, amino acid mixture simulating soya-bean protein or casein; Lys, lysine; Arg, arginine; HDL, high-density-lipoprotein; LDL, low-density-lipoprotein (including very-low-density-lipoprotein).

\section{Serum apolipoprotein concentration}

Table 4 summarizes the results obtained for the concentration of apolipoproteins A-I, B and $\mathrm{E}$. The concentration of apo $\mathrm{A}-\mathrm{I}$ was significantly lower in rats given soya-bean protein than in those given casein. The same pattern of response was observed with the amino acid mixture simulating these proteins. Soya-bean protein and its amino acid mixture produced an increase in apo B content by comparison with the response to the corresponding casein diets. The concentration of apo $\mathrm{E}$ was affected only when the animals were fed on the amino acid mixture and it tended to increase in the casein-amino acid group. The addition of lysine or arginine did not influence these responses.

The effect of dietary proteins on the concentration of serum hydroperoxide was less well defined, although feeding the casein-amino-acid diet supplemented with arginine caused an increase in the hydroperoxide level as compared with the soya-bean protein-aminoacid-mixture diet supplemented with lysine.

\section{Faecal excretion of steroids}

Table 5 shows the excretion of neutral and acidic steroids. Rats given soya-bean protein excreted larger amounts of faeces and neutral and acidic seroids than those given casein. Interestingly, these differences disappeared when the animals were given the amino acid mixture as an $\mathrm{N}$ source; there was a marked decrease in faecal weight with the soya-bean protein-amino-acid-mixture diet, but not with the casein-amino-acid diet when compared with the corresponding protein diets. Due to this decrease, faecal output of steroids was apparently similar for the two amino acid mixture groups. Neither lysine nor arginine supplementation modified the pattern of responses observed with proteins or amino acid mixtures. 
Table 4. Concentration of serum apolipoproteins $(\mu \mathrm{g} / \mathrm{ml})$ and hydroperoxide $(\mathrm{nmol} / \mathrm{ml})$ in rats given soya-bean protein or casein

(Mean values with their standard errors for six rats/dietary group)

\begin{tabular}{|c|c|c|c|c|c|c|c|c|c|}
\hline \multirow{2}{*}{$\begin{array}{l}\text { Expt } \\
\text { no. }\end{array}$} & \multirow[b]{2}{*}{ Dietary regimens } & \multicolumn{2}{|c|}{ Apo A-I } & \multicolumn{2}{|c|}{ Apo B } & \multicolumn{2}{|c|}{ Apo E } & \multicolumn{2}{|c|}{ Hydroperoxide } \\
\hline & & Mean & SE & Mean & SE & Mean & SE & Mean & SE \\
\hline (1) & $\begin{array}{l}\text { Soya-bean protein } \\
\text { Casein } \\
\text { Soya AA mix } \\
\text { Casein AA mix }\end{array}$ & $\begin{array}{r}588 \\
838 \\
647 \\
1015\end{array}$ & $\begin{array}{l}56^{\mathrm{a}} \\
42^{\mathrm{b}} \\
25^{\mathrm{a}} \\
69^{\mathrm{b}}\end{array}$ & $\begin{array}{l}340 \\
205 \\
305 \\
238\end{array}$ & $\begin{array}{r}12^{\mathrm{a}} \\
16^{\mathrm{b}} \\
7^{\mathrm{a}} \\
22^{\mathrm{b}}\end{array}$ & $\begin{array}{l}311 \\
265 \\
285 \\
314\end{array}$ & $\begin{array}{l}22 \\
20 \\
28 \\
14\end{array}$ & $\begin{array}{l}2.1 \\
1.7 \\
1.7 \\
1.6\end{array}$ & $\begin{array}{l}0 \cdot 1^{\mathrm{a}} \\
0 \cdot 2^{\mathrm{ab}} \\
0 \cdot 2^{\mathrm{ab}} \\
0 \cdot 2^{\mathrm{b}}\end{array}$ \\
\hline (2) & $\begin{array}{l}\text { Soya-bean protein } \\
\text { Soya-bean protein }+ \text { Lys } \\
\text { Casein } \\
\text { Casein }+ \text { Arg }\end{array}$ & $\begin{array}{r}602 \\
612 \\
1037 \\
977\end{array}$ & $\begin{array}{r}29^{\mathrm{a}} \\
19^{\mathrm{a}} \\
122^{\mathrm{b}} \\
37^{\mathrm{b}}\end{array}$ & $\begin{array}{l}239 \\
212 \\
101 \\
106\end{array}$ & $\begin{array}{l}19^{\mathrm{a}} \\
35^{\mathrm{a}} \\
10^{\mathrm{b}} \\
23^{\mathrm{b}}\end{array}$ & $\begin{array}{l}245 \\
258 \\
239 \\
266\end{array}$ & $\begin{array}{l}27 \\
14 \\
19 \\
10\end{array}$ & $\begin{array}{l}2 \cdot 6 \\
2 \cdot 0 \\
2 \cdot 2 \\
2 \cdot 9\end{array}$ & $\begin{array}{l}0.8 \\
0.9 \\
0.6 \\
1.2\end{array}$ \\
\hline (3) & $\begin{array}{l}\text { Soya AA mix } \\
\text { Soya AA mix + Lys } \\
\text { Casein AA mix } \\
\text { Casein AA mix + Arg }\end{array}$ & $\begin{array}{r}695 \\
834 \\
1091 \\
915\end{array}$ & $\begin{array}{l}35^{\mathrm{a}} \\
54^{\mathrm{ac}} \\
75^{\mathrm{b}} \\
76^{\mathrm{bc}}\end{array}$ & $\begin{array}{l}139 \\
130 \\
112 \\
120\end{array}$ & $\begin{array}{r}13 \\
8 \\
12 \\
14\end{array}$ & $\begin{array}{l}321 \\
329 \\
412 \\
473\end{array}$ & $\begin{array}{l}30^{\mathrm{a}} \\
22^{\mathrm{a}} \\
24^{\mathrm{b}} \\
33^{\mathrm{b}}\end{array}$ & $\begin{array}{l}1.8 \\
1.6 \\
1.8 \\
2.3\end{array}$ & $\begin{array}{l}0.1^{\mathrm{ab}} \\
0.1^{\mathrm{a}} \\
0.2^{\mathrm{ab}} \\
0.3^{\mathrm{b}}\end{array}$ \\
\hline
\end{tabular}

a, b, c. In each experiment, values in the same vertical column not sharing common superscript letters were significantly different; $P<0.05-0.01$.

AA mix, amino acid mixture simulating soya-bean protein or casein; Lys, lysine; Arg, arginine.

Table 5. Faecal excretion of endogenous neutral and acidic steroids in rats given soya-bean protein or casein

(Mean values with their standard errors of six rats/dietary group)

\begin{tabular}{|c|c|c|c|c|c|c|c|c|c|c|c|}
\hline \multirow{3}{*}{$\begin{array}{c}\text { Expt } \\
\text { no. }\end{array}$} & \multirow[b]{3}{*}{ Dietary regimens } & \multirow{2}{*}{\multicolumn{2}{|c|}{$\begin{array}{l}\text { Faeces } \\
\text { excreted } \\
(\mathrm{g} / \mathrm{d})\end{array}$}} & \multicolumn{6}{|c|}{ Neutral steroids (mg/d) } & \multirow{2}{*}{\multicolumn{2}{|c|}{$\begin{array}{l}\text { Acidic } \\
\text { steroids } \\
(\mathrm{mg} / \mathrm{d})\end{array}$}} \\
\hline & & & & \multicolumn{2}{|c|}{ Coprostanol } & \multicolumn{2}{|c|}{ Cholesterol } & \multicolumn{2}{|c|}{ Total } & & \\
\hline & & Mean & $\mathbf{S E}$ & Mean & $\mathbf{S E}$ & Mean & SE & Mean & SE & Mean & SE \\
\hline (1) & $\begin{array}{l}\text { Soya-bean protein } \\
\text { Casein } \\
\text { Soya AA mix } \\
\text { Casein AA mix }\end{array}$ & $\begin{array}{l}1 \cdot 2 \\
0 \cdot 9 \\
0 \cdot 9 \\
0 \cdot 8\end{array}$ & $\begin{array}{l}0.1^{\mathbf{a}} \\
0 \cdot 1^{\mathbf{b}} \\
0 \cdot 1^{\mathbf{b}} \\
0 \cdot 1^{\mathrm{b}}\end{array}$ & $\begin{array}{l}6 \cdot 30 \\
3.53 \\
5.93 \\
5.99\end{array}$ & $\begin{array}{l}0.69^{\mathrm{a}} \\
0.39^{\mathrm{b}} \\
0 \cdot 74^{\mathrm{a}} \\
0.71^{\mathrm{a}}\end{array}$ & $\begin{array}{l}2.45 \\
1.41 \\
1.93 \\
1.50\end{array}$ & $\begin{array}{l}0 \cdot 16^{\mathrm{a}} \\
0 \cdot 17^{\mathrm{b}} \\
0 \cdot 35^{\mathrm{ab}} \\
0 \cdot 17^{\mathrm{b}}\end{array}$ & $\begin{array}{l}8 \cdot 75 \\
4 \cdot 94 \\
7 \cdot 86 \\
7 \cdot 34\end{array}$ & $\begin{array}{l}0.81^{\mathrm{a}} \\
0.44^{\mathrm{b}} \\
0.61^{\mathrm{a}} \\
0.80^{\mathrm{a}}\end{array}$ & $\begin{array}{c}12 \cdot 6 \\
4 \cdot 84 \\
7 \cdot 19 \\
6 \cdot 19\end{array}$ & $\begin{array}{l}0.92^{\mathrm{a}} \\
1.01^{\mathrm{b}} \\
1.0^{\mathrm{b}} \\
0.69^{\mathrm{b}}\end{array}$ \\
\hline (2) & $\begin{array}{l}\text { Soya-bean protein } \\
\text { Soya-bean protein }+ \text { Lys } \\
\text { Casein } \\
\text { Casein + Arg }\end{array}$ & $\begin{array}{l}1 \cdot 0 \\
0 \cdot 9 \\
0 \cdot 8 \\
0 \cdot 7\end{array}$ & $\begin{array}{l}0 \cdot 1^{\mathrm{a}} \\
0 \cdot 1^{\mathrm{ab}} \\
0 \cdot 1^{\mathrm{b}} \\
0 \cdot 0^{\mathrm{b}}\end{array}$ & $\begin{array}{l}5 \cdot 84 \\
5 \cdot 40 \\
3 \cdot 64 \\
3 \cdot 55\end{array}$ & $\begin{array}{l}0.48^{\mathrm{a}} \\
0.47^{\mathrm{a}} \\
0.23^{\mathrm{b}} \\
0.44^{\mathrm{b}}\end{array}$ & $\begin{array}{l}2 \cdot 07 \\
1 \cdot 56 \\
1 \cdot 17 \\
1 \cdot 03\end{array}$ & $\begin{array}{l}0.29^{\mathrm{a}} \\
0.21^{\mathrm{ab}} \\
0.23^{\mathrm{b}} \\
0.23^{\mathrm{b}}\end{array}$ & $\begin{array}{l}7.91 \\
6.96 \\
4.80 \\
4.59\end{array}$ & $\begin{array}{l}0.73^{\mathrm{a}} \\
0.73^{\mathrm{ab}} \\
0.45^{\mathrm{b}} \\
0.61^{\mathrm{b}}\end{array}$ & $\begin{array}{c}9.32 \\
11 \cdot 5 \\
4.42 \\
3.67\end{array}$ & $\begin{array}{l}0.45^{\mathrm{a}} \\
0.96^{\mathrm{a}} \\
0.59^{\mathrm{b}} \\
0.62^{\mathrm{b}}\end{array}$ \\
\hline (3) & $\begin{array}{l}\text { Soya AA mix } \\
\text { Soya A A mix + Lys } \\
\text { Casein AA mix } \\
\text { Casein AA mix + Arg }\end{array}$ & $\begin{array}{l}0 \cdot 7 \\
0 \cdot 8 \\
0 \cdot 7 \\
0 \cdot 7\end{array}$ & $\begin{array}{l}0.1 \\
0.1 \\
0.1 \\
0.0\end{array}$ & $\begin{array}{l}4.02 \\
5.54 \\
4.59 \\
5.09\end{array}$ & $\begin{array}{l}0.85 \\
0.25 \\
0.49 \\
0.06\end{array}$ & $\begin{array}{l}1.61 \\
1 \cdot 19 \\
0.89 \\
0.98\end{array}$ & $\begin{array}{l}0.72 \\
0.21 \\
0.13 \\
0.18\end{array}$ & $\begin{array}{l}5.64 \\
6.73 \\
5.47 \\
6.07\end{array}$ & $\begin{array}{l}0.60 \\
0.30 \\
0.52 \\
0.40\end{array}$ & $\begin{array}{l}5.32 \\
5.64 \\
5.55 \\
6.08\end{array}$ & $\begin{array}{l}0.46 \\
0.77 \\
0.25 \\
0.46\end{array}$ \\
\hline
\end{tabular}

$a, b$, In each experiment, values in the same vertical column not sharing common superscript letters were significantly different; $P<0.05-0.01$.

AA mix, amino acid mixture simulating soya-bean protein or casein; Lys, lysine; Arg, arginine.

* Weight of lyophilized faeces. 


\section{DISCUSSION}

Although we have previously reported that the hypocholesterolæmic effect of the soya-bean protein isolate, as compared with casein, can be demonstrated only when the rats were fed a low-fat diet free of cholesterol (Nagata et al. 1980), it was not obvious if the difference in the amino acid composition of these two proteins could be responsible for causing different responses in serum cholesterol levels. The results obtained with the aminoacid-mixture diet apparently indicated that the difference in the amino acid composition did in fact account for the cholesterol-lowering action of soya-bean protein. Yadav \& Liener (1977) came to a similar conclusion, though they possibly ignored the effect of essentialfatty-acid deficiency on the cholesterol metabolism. In rabbits, the cholesterol-lowering action became obscure when the amino acid mixture replaced the protein (Huff et al. 1977). However, the present results support the view that the amino acid composition itself is responsible for the hypocholesterolæmic effect of soya-bean protein.

If the difference in the amino acid composition is a major factor regulating the concentration of serum cholesterol of rats, then the question arises as to which amino acid(s) has most influence on the serum cholesterol level. Recently Kritchevsky (1979) and Czarnecki \& Kritchevsky (1979) studied the effect of the difference in arginine:lysine (1.13 in soya-bean protein and 0.49 in casein) on serum cholesterol of rabbits. The results indicate that arginine:lysine was responsible for controlling serum cholesterol levels, and they concluded that the anti-atherogenecity of soya-bean protein could be weakened by the addition of specific amino acid, lysine in this instance. By contrast, according to the reports of Jarowski and co-workers, dietary lysine appeared to lower plasma cholesterol of rats (Jarowski \& Pytelewski, 1975) and hyperlipidemic subjects (Raja \& Jarowski, 1975). In our experiments, addition of lysine to soya-bean protein or arginine to casein did not modify the intrinsic effect of these proteins on serum cholesterol.

Hamilton \& Carroll (1976), Gatti \& Sirtori (1977) and Kim et al. (1978) noted the differences in methionine content because casein contains twice as much methionine as soya-bean protein and this sulphur amino acid is the first limiting amino acid in both proteins. The addition of methionine to soya-bean protein did not raise serum cholesterol levels, indicating the possible independence of the hypocholesterolæmic effect of vegetable protein to the level of this amino acid. Recently, Hermus and associates (Hermus \& Dallinga-Thie, 1979; Katan et al. 1980) have shown that the dietary level of glycine is related to the anti-hypocholesterolæmic action of casein. From these studies it seems likely that the concentration of serum cholesterol is determined not only by specific amino acid(s) but also by the interplay of component amino acids as a whole.

Soya-bean protein decreased serum cholesterol in both the HDL and VLDL plus LDL fractions to a similar extent, whereas there was a significant decrease in serum apo A-I and increase in apo B. Though the evaluation of the changes in the apolipoprotein profiles due to feeding the vegetable protein seemed very difficult, these phenomena may relate to the difference in the supply of apo A-I from the intestine and apo B from the liver (Christophe \& Verdonk, 1979). There is a possibility that the serum from rats given casein carries an extra amount of apo A-I and that the level observed with the animals given soya-bean protein is by no means subnormal. The small decrease in the concentration of HDLcholesterol with a concomitant large decrease in cholesterol of intermediate-density lipoprotein has been observed in rabbits given soya-bean protein as compared with casein (Carroll et al. 1977). In the human, LDL-cholesterol appeared to decrease, but the level of HDL-cholesterol remained almost unchanged (Sirtori et al. 1977, 1979). A part of these discrepancies among animals may be explained by the species-specific distribution of serum 
cholesterol in lipoproteins. The present observation at least indicates the characteristic modification of cholesterol metabolism by the type of dietary proteins.

It has been considered that the increase in faecal excretion of neutral steroids is a factor responsible for causing a low level of serum cholesterol after feeding soya-bean protein (Fumagalli et al. 1978). This factor held true in a previous experiment (Nagata et al. 1980). However, when the amino acid mixtures simulating soya-bean protein or casein were fed, the difference in the excretion of steroids disappeared. Thus, the dietary-protein-dependent difference in serum cholesterol cannot necessarily be explained by the increased faecal output of steroids alone. The increase in faecal steroids on feeding the vegetable protein appears to be counterbalanced partly by the decrease in the pool of hepatic cholesterol; such a reduction was not observed in rats given the amino acid mixture diet. Fumagalli et al. (1978) demonstrated in rabbits that soya-bean protein caused an increase in faecal excretion of neutral, but not acidic steroids. By contrast, there was no difference in the amount of faecal steroids in pigs given soya-bean protein and casein despite a difference in serum cholesterol levels (Kim et al. 1978). In the present study, soya-bean protein increased the excretion of both neutral and acidic steroids. These differences may be induced by species specificity in the metabolism of cholesterol.

The present results indicate that the increase in faecal excretion of steroids is not the only factor causing a low level of serum cholesterol in rats given the vegetable protein. Another possible factor associated with the hypocholesterolæmic effect of soya-bean protein may be an increased turnover of cholesterol in the rapidly-exchangeable pool. It has been known that feeding soya-bean protein to rats, in comparison with casein, results in the elevation of the activity of 3-hydroxy-3-methylglutaryl coenzyme $A$ reductase $(E C$ 1.1.1.34), the rate-limiting enzyme in cholesterogenesis (Reiser et al. 1977).

The authors thank Dr K. Imaizumi and Mr Y. Abiru for the apolipoprotein assays and Mr Y. Miyashita for technical assistance. The soya-bean protein isolate was kindly provided by Fuji Oil Co., Osaka and amino acids by Ajinomoto Co., Tokyo and Kyowa Hakko Kogyo Co., Tokyo. This study was supported by the Grant-in-Aid for Special Project Research (no. 412008) from the Ministry of Education, Science and Culture.

\section{REFERENCES}

Belton, E. A. \& Truswell, A. S. (1978). Proc. Nutr, Soc. 37, 12A.

Burnstein, M., Scholnick, H. R. \& Morfin, R. (1970). J. Lipid Res. 11, 583.

Carroll, K. K., Giovanetti, P. M., Huff, M. W., Moase, O., Roberts, D. C. K. \& Wolfe, B. M. (1978). Am. J. clin. Nutr. 31, 1312.

Carroll, K. K. \& Hamilton, R. M. G. (1975). J. Fd Sci. 40, 18.

Carroll, K. K., Huff, M. W. \& Roberts, D. C. K. (1977). In Atherosclerosis, vol. 4, pp. 445-448 [G. Schettler, Y. Goto, Y. Hata and G. Klose, editors]. Berlin, Heidelberg, New York: Springer-Verlag.

Christophe, A. \& Verdonk, G. (1979). Arch. int. Physiol. Biochim. 87, 784.

Czarnecki, S. K. \& Kritchevsky, D. (1979). J. Am. Oil Chem. Sac. 56, 388A.

Ebihara, K., Imamura, Y. \& Kiriyama, S. (1979). J. Nutr. 109, 2106.

Fisher, R. A. (1970). Statistical Methods for Research Workers, 14th ed. pp. 140-142. Edinburgh: Oliver \& Boyd.

Fumagalli, R., Paoletti, R. \& Howard, A. N. (1978). Life Sci. 22, 947.

Gatti, E. \& Sirtori, C. R. (1977). Lancet i, 805.

Grundy, S. M., Ahrens, E. H. \& Miettinen, T. A. (1965). J. Lipid Res. 6, 397.

Hamilton, R. M. G. \& Carroll, K. K. (1976). Atherosclerosis 24, 47.

Harper, A. E. (1959). J. Nutr. 68, 405.

Hermus, R. J. J. \& Dallinga-Thie, G. M. (1979). Lancet ii, 48.

Hevia, P., Clary, R. A. \& Visek, W. J. (1979). Nutr. Rep. int. 20, 539.

Hevia, P. \& Visek, W. J. (1979). J. Nutr. 109, 32.

Huff, M. W. \& Carroll, K. K. (1977). Fedn Proc. Fedn Am. Socs exp. Biol. 36, 1104.

Huff, M. W., Hamilton, R. M. G. \& Carroll, K. K. (1977). Atherosclerosis 28, 187.

Imaizumi, K., Fainaru, M. \& Havel, R. J. (1978). J. Lipid Res. 19, 712.

Jarowski, C. I. \& Pytelewski, R. (1975). J. pharmac. Sci. 64, 690. 
Katan, M. B., Vroomen, L. \& Hermus, R. J. J. (1980). 7th int. Symp. Drugs Affecting Lipid Metabolism, Milan, Abstr. p. 100.

Kim, D. N., Lee, K. T., Reiner, J. M. \& Thomas, W. A. (1978). Exp. mol. Pathol. 29, 385.

Kritchevsky, D. (1979). J. Am. Oil Chem. Soc. 56, 135.

Kritchevsky, D., Tepper, S. A., Williams, D. E. \& Story, J. A. (1977). Atherosclerosis 26, 397.

Miettinen, T. A., Ahrens, E. H. \& Grundy, S. M. (1965). J. Lipid Res. 6, 411.

Nagata, Y., Imaizumi, K. \& Sugano, M. (1980). Br. J. Nutr. 44, 113.

Neves, L. B., Clifford, C. K., Kohler, G. O., Fremery, D. D., Knuckles, B. E., Cheowtirakul, C., Miller, M. W., Weir, W. C. \& Clifford, A. J. (1980). J. Nutr. 110, 732.

Noseda, G., Fragiacomo, C., Bosia, C., Ramelli, F. \& Sirtori, C. R. (1979). Schweiz. med. Wschr. 109, 1852.

Oakenfull, D. G., Fenwick, D. E., Hood, R. L., Topping, D. L., Illmann, R. L. \& Storer, G. B. (1979). Br. J. Nutr. 42, 209.

Potter, J. D., Topping, D. L. \& Oakenfull, D. G. (1979). Lancet i, 223.

Raja, P. K. \& Jarowski, C. I. (1975). J. pharmac. Sci. 64, 691.

Reiser, R., Henderson, G. R., O'Brien, B. C. \& Thomas, J. (1977). J. Nutr. 107, 453.

Sautier, C., Doucet, C., Flament, C. \& Lemonnier, D. (1979). Atherosclerosis 34, 233.

Sirtori, C. R., Agradi, E., Conti, F., Mantero, O. \& Gatti, E. (1977). Lancet i, 275.

Sirtori, C. R., Gatti, E., Mantero, O., Conti, F., Agradi, E., Tremoli, E., Sirtori, M., Fraterrigo, L., Tavazzi, L. \& Kritchevsky, D. (1979). Am. J. clin. Nutr. 32, 1645.

Yadav, N. R. \& Liener, I. E. (1977). Nutr. Rep. int. 16, 385.

Yagi, K. (1976). Biochem. Med. 15, 212. 